\title{
RAB44 wt Allele
}

National Cancer Institute

\section{Source}

National Cancer Institute. RAB44 wt Allele. NCI Thesaurus. Code C162427.

Human RAB44 wild-type allele is located in the vicinity of 6 p21.2 and is approximately 35 $\mathrm{kb}$ in length. This allele, which encodes Ras-related protein Rab-44, plays a role in neutrophil degranulation. A fusion involving this gene and the TP53 gene may be associated with osteosarcoma. 